\title{
Cooking process evaluation on mercury content in fish
}

\author{
Luciana Aparecida FARIAS ${ }^{1}$, Déborah Inês FÁVARO², José Osman SANTOS³, Marina Beatriz \\ VASCONCELLOS ${ }^{4}$, Artemiza PESSÔA5 ${ }^{5}$ Jaime Paiva Lopes AGUIAR ${ }^{6}$, Lucia YUYAMA
}

\section{ABSTRACT}

This study evaluated different cooking processes (roasted, cooked and fried) on total mercury $(\mathrm{Hg})$ content in fish species most consumed by Manaus residents and surrounding communities, Amazon region. The results obtained for total $\mathrm{Hg}$ in natura and after the three types of preparation (roasted, cooked and fried) for 12 fish species showed a significant $\mathrm{Hg}$ concentration variation. In the present study the cooked and frying processes resulted in higher Hg losses for Pacu, Pescada, Jaraqui, Curimatá, Surubin and Aruanã fish species, most of them presenting detritivorous and carnivorous feeding habits. The higher $\mathrm{Hg}$ losses in the roasting process occurred for Sardinha, Aracu, Tucunaré, Pirapitinga, Branquinha and Tambaqui fish species, most of them being omnivorous and herbivorous fish species. Some micronutrients ( $\mathrm{Ca}, \mathrm{Fe}, \mathrm{K}, \mathrm{Na}, \mathrm{Se}$ and $\mathrm{Zn}$ ) in fish species in natura were also determined in order to perform a nutritional evaluation regarding these micronutrients.

KEYWORDS: mercury; cooking processes; fish; nutrition; micronutrients.

\section{Influência do processo de cocção no teor de mercúrio em peixes}

\section{RESUMO}

O presente estudo avaliou três diferentes processos de cocção (assado, cozido e frito) e sua relação com o teor de mercúrio total $(\mathrm{Hg})$ em espécies de peixes comumente consumidas pela população de Manaus e comunidades vizinhas da regiáo Amazônica. Os resultados obtidos para $\mathrm{Hg}$ total in natura (antes) e após os três tipos de preparo (assado, cozido e frito) para as 12 espécies de peixes selecionadas apresentaram uma significativa variação na concentração. Os processos de cozimento e fritura resultaram em maiores perdas de Hg para as espécies Pacu, Pescada, Jaraqui, Curimatá, Surubin e Aruanã sendo a maioria delas classificadas como espécies detritívoras e carnívoras. As maiores perdas de $\mathrm{Hg}$ no processo assado ocorreram para as espécies Sardinha, Aracu, Tucunaré, Pirapitinga, Branquinha e Tambaqui, a maioria classificadas como espécies omnivoras e herbivoras. Alguns micronutrientes ( $\mathrm{Ca}, \mathrm{Fe}, \mathrm{K}, \mathrm{Na}, \mathrm{Se}$ e $\mathrm{Zn}$ ) nas espécies de peixes in natura foram determinados com o objetivo de fazer uma avaliação nutricional em relação a esses constituintes.

PALAVRAS-CHAVE: mercúrio; processo de cocção; peixe; nutrição; micronutrientes.

\footnotetext{
1 Instituto de Pesquisas Energéticas e Nucleares; Email: lufarias2@yahoo.com.br

2 Instituto de Pesquisas Energéticas e Nucleares; Email: ditfavaro@yahoo.com.br

${ }^{3}$ CEFET - Aracaju - SE; Email: josantos@ipen.br

${ }^{4}$ Instituto de Pesquisas Energéticas e Nucleares; Email: mbvascon@ipen.br

${ }^{5}$ Instituto Nacional de Pesquisas da Amazônia; Email: nutri.pessoa@gmail.com

${ }^{6}$ Instituto Nacional de Pesquisas da Amazônia; Email: jaguiar@inpa.gov.br

7 Instituto Nacional de Pesquisas da Amazônia; Email: yuyama@inpa.gov.br
} 
Influência do processo de cocção no teor de mercúrio em peixes

\section{INTRODUCTION}

Throughout time man has been exposed to different forms of mercury $(\mathrm{Hg})$, and methylmercury $(\mathrm{MeHg})$ contamination. It is well known that both freshwater and sea fish consumption are directly and closely related to increases of blood and hair mercury (Hg) contents (Clarkson, 2002; UNEP, 2002; Farias et al., 2006). Furthermore, fish are culturally vital for many communities and constitute the main source of protein and other micronutrients. The highest levels of $\mathrm{Hg}$ are found in the predatory fish at the top of the food chain due to bioaccumulation. More than $90 \%$ of the total $\mathrm{Hg}$ in certain fish tissues is $\mathrm{MeHg}$ (US EPA, 2001; Chien et al, 2007). This poses a particular threat to public health as this toxic species of $\mathrm{Hg}$ is mainly accumulated in fish.

Several researchers have addressed the issues surrounding the risks and benefits associated with fish consumption. On the other hand, there is much information regarding $\mathrm{Hg}$ and other essential element content in several fish species, portraying the chemical composition of fish in nature. There is very little information regarding chemical composition for fish prepared for human consumption. Considering the relatively high temperature used in the different methods of cooking and the volatile characteristic of $\mathrm{MeHg}$, such treatments might sometimes reduce the content of this compound. This question has been explored in a number of laboratories around the world, but there has been no consensus as to the true status of this reduction (Moretti et al., 1990; Morgan et al., 1997; Hernández-García et al., 1998; Chicourel et al., 2001). The present study evaluated the content of total $\mathrm{Hg}$ in natura (without any cooking process) and after different cooking processes. Three types of preparation (roasted, cooked and fried) commonly used by Manaus residents to prepare fish for consumption was tested. The purpose of this study was to assess if there were any losses of $\mathrm{Hg}$ due to cooking. Some micronutrients (Ca, Fe, $\mathrm{Na}$, Se and $\mathrm{Zn}$ ) in fish species in natura were also determined in order to perform a nutritional evaluation regarding these micronutrients.

\section{MATERIAL AND METHODS}

\section{Description of the Studied Area}

Manaus, the capital of the Amazon State, is located in the north region of Brazil. It is the entrance to the Amazon region. It is also the world's largest ecological region. Official data puts the population at 2.006.870 inhabitants (IBGE, 2009). The city is located on the Negro River banks. This river is a black water river which receives drain water from the Amazon ecosystem. It has been well documented that black water systems are subject to flooding which result in biogeochemical characteristics that favor $\mathrm{Hg}$ methylation in the aquatic biota (Silva-Forsberg, 1999; Fadini \& Jardim, 2001).

\section{Sampling and Sample Preparation}

The fish samples were collected in October 2004 from the fishing boats that operate from the central receiving market (CEASA) in Manaus. These samples came from the Ariaú and Puraquequara lakes as well as, Autazes, Codajás, Careiro and Terra Nova counties. The quality indicators of fish and external organoleptic characteristics (eyes, gills and scales) were assessed at the time of purchase. All fish samples were prepared at the CPTA laboratory (Centro de Pesquisas em Tecnologia de Alimentos) from INPA (Amazon National Research Institute). The species evaluated were: Aracu (Schizodar sp), Aruanã (Osteoglossum bicirrhossum), Branquinha (Curimata laticeps), Curimatã (Prochilodus nigricans), Jaraqui (Prochilodus insignis sp), Pacu (Mylossoma spp), Pescada (Plagioscion spp), Pirapitinga (Piractus brachypomum), Sardinha (Triportheus elongatus spp), Surubim (Pseudoplalystoma fasciatum), Tambaqui (Colossoma macropomum) and Tucunaré (Cichla ocellaris $s p p$ ). Three individuals of each fish species were used for the cooking process preparation. Due to the large fish size Pescada, Pirapitinga, Surubim, Tambaqui and Tucunaré were cut in slices and prepared.

All samples were cooked using the three cooking processes:

Fried - samples were wrapped in wheat flour, weighed and fried in soybean oil in a temperature of about $180^{\circ} \mathrm{C}$. Afterwards the edible parts were separated. Salt concentration was defined in this study as $1 \%$ of the weight of each fish sample. The amount of wheat flour needed to cook the fish was $25 \mathrm{~g}$, sufficient for both, whole and sliced fish. Seventy five $\mathrm{mL}$ of soybean oil was used for frying.

Cooked - Onions, garlic, pepper, parsley and colorific were fried in about $3 \mathrm{~g}$ of oil and then the fish added and cooked in boiling water and salt. The temperature used was about $105^{\circ} \mathrm{C}$. After which the edible parts were separated. The amount of water used for cooking corresponded to the weight of each fish sample. Salt was added to the water before cooking $(1 \%$ of the fish sample weight). The amount of colorific was $0.5 \mathrm{~g}$. Garlic, onion and pepper were not quantified.

Roasted - The fish, after seasoning with salt were weighed and roasted over coal during different time periods, according to the type and size of the fish. The temperature used was about $150^{\circ} \mathrm{C}$. Afterwards the edible parts were separated. Salt concentration was $1 \%$ of the weight of each fish sample.

Once separated, the edible parts (muscle) of each fish species were pooled and then grounded, homogenized and sent for analysis at IPEN/CNEN-SP.

Total $\mathrm{Hg}$ determination was made by means of cold vapor atomic absorption technique (CV AAS) and $\mathrm{Ca}, \mathrm{Fe}, \mathrm{K}, \mathrm{Na}$, Se and $\mathrm{Zn}$ by instrumental neutron activation analysis (INAA) techniques. All the results are expressed in dry weight basis. 
Influência do processo de cocção no

teor de mercúrio em peixes

\section{Apparatus and reagents}

All reagents were of analytical grade. High purity water, of $18 \mathrm{M} \Omega \mathrm{cm}^{-1}$ resistivity was obtained using Milli-Q system. The $\mathrm{Hg}$ stock solution (1255 $\mathrm{mg} \mathrm{L}^{-1}$ ) was acquired by dissolving $\mathrm{HgO}$ (Johnson Matthey Chemicals Limited) in $\mathrm{HNO}_{3}$.

In $\mathrm{Hg}$ determinations, meticulous cleaning of the materials is essential. All glassware used was soaked for 24 hours in Extran $2 \%(\mathrm{v} / \mathrm{v})$, and rinsed with high purity water. Next, it was rinsed with high purity water, soaked for 72 hour in $20 \%(\mathrm{v} / \mathrm{v}) \mathrm{HNO}_{3}$ and finally rinsed with high purity water for at least three times.

\section{Total Hg Determination}

Roughly 200 to $500 \mathrm{mg}$ of pool samples for each fish species were digested with a mixture of concentrated $\mathrm{HNO}_{3}$ and $\mathrm{H}_{2} \mathrm{SO}_{4}$ in Teflon vials. The vials were closed and left overnight at room temperature. The following day, the vials were put into an aluminum block at $90{ }^{\circ} \mathrm{C}$ and left there for 3 hours. The samples were allowed to cool at room temperature and the final volume was completed to $50 \mathrm{~mL}$ with Milli-Q water. Total Hg determination was performed by CV AAS, using a FIMS (Flow Injection Mercury System) from Perkin Elmer (Massachusetts, USA). The analytical procedure (wet digestion) was that of Horvat (1996), with some modifications. Methodology validation for total $\mathrm{Hg}$ determination was carried out by means of reference material analyses Dogfish muscle (DORM-1, NRCC). The detection limit for this method was established in agreement with studies found in the literature for $\mathrm{Hg}$ determination (Horvat, 1996). Ten blank solutions were prepared and measured in order to establish the mean value (X) and the standard deviation (s). The detection limit was calculated using the formula (LD $=\mathrm{X}+3 \mathrm{~s}$ ) and the value $0.5 \mathrm{ng} \mathrm{mL}^{-1}$ was found. Details of the analytical methodology have already been described in a previous paper (Farias et al, 2009).

\section{INAA determination for micronutrients}

For multielemental analysis, approximately $200 \mathrm{mg}$ of fish (duplicate samples) and about $150 \mathrm{mg}$ of reference materials were accurately weighed and sealed in pre-cleaned double polyethylene bags, for irradiation. Single and multi-element synthetic standards were prepared by pipetting convenient aliquots of standard solutions from Assurance ${ }^{\circledR}$ Multi-Element Solution Standards (SPEX CERTIPREP, USA), onto small sheets of Whatman no 41 filter paper. Fish samples, reference materials and synthetic standards were irradiated for 8 hours, under a thermal neutron flux of $10^{12} \mathrm{~cm}^{-2} \mathrm{~s}^{-1}$ in the IEA-R1 nuclear research reactor at IPEN. The elements determined by INAA were $\mathrm{Ca}, \mathrm{Fe}, \mathrm{K}, \mathrm{Na}, \mathrm{Se}$ and $\mathrm{Zn}$. The precision and accuracy of the method were verified by measuring the reference materials Orchard Leaves (OL) (NIST SRM 1571), Tomato Leaves (TL) (NIST SRM 1573a) and Oyster
Tissue (OT) (NIST SRM 1566b). Details of the analytical methodology have already been described in a previous paper (Favaro et al, 2000).

\section{Statistical Analysis}

Kruskal-Walis test was applied to the data for median comparison $(\mathrm{Hg}$ results, $\mathrm{p}<0.05)$ in order to statistically evaluate the variations observed and if they were significant or not (level of significance 5\%). The Kruskal-Walis test was applied after the Shapiro-Wilks test $(\mathrm{p}<0.05)$ showed that results for $\mathrm{Hg}$ did not have normal distribution. In the present study we also used multivariate statistical techniques, principal component analysis (PCA) and discriminate analysis, to identify sample groups with similar chemical composition for the determined elements. The statistical analyzes were performed using the Statistica Package, Statistica Student Version 6.0. (Tulsa, OK, USA).

\section{RESULTS AND DISCUSSION}

\section{Total mercury methodology validation}

The precision and accuracy of the method for total mercury were verified by means of the reference material analysis: Dogfish Muscle (DORM-1 - NRCC). The results obtained showed good precision and accuracy with relative standard deviation of $5.4 \%$ and relative error of $0 \%$ (Table 1 ).

Table 1 - Results of total $\mathrm{Hg}\left(\mathrm{mg} \mathrm{kg}^{-1}\right)$ in the reference materials $(\mathrm{n}=7)^{\mathrm{a}}$

\begin{tabular}{lcccc}
\hline $\begin{array}{l}\text { Reference } \\
\text { Materials }\end{array}$ & $\begin{array}{c}\mathrm{Hg}^{2} \text { total }\left(\mu \mathrm{gg}^{-1}\right) \\
\text { (mean } \pm \text { s.d.) }\end{array}$ & $\begin{array}{c}\text { Certified Value } \\
\left(\mu \mathrm{g} \mathrm{kg}^{-1}\right)\end{array}$ & $\begin{array}{c}\mathrm{RSD} \\
(\%)\end{array}$ & $\begin{array}{c}\mathrm{RE} \\
(\%)\end{array}$ \\
\hline $\begin{array}{l}\text { DORM-1 NRCC } \\
\text { (Dogfish Muscle) }\end{array}$ & $798 \pm 43$ & $798 \pm 74$ & 5.4 & 0 \\
\hline a $\mathrm{n}=$ number of determinations; $\mathrm{RSD}=$ Relative standard deviation; & $\mathrm{RE}=$ relative
\end{tabular}

$\mathrm{a}=$ number of determinations; $\mathrm{RSD}=$ Relative standard deviation; $\mathrm{RE}=$ relative error

\section{INAA methodology validation}

The precision and accuracy of the method were verified by measuring the reference materials: Tomato Leaves (TL) (NIST SRM 1573), Orchard Leaves (OL) (NIST SRM 1571) and Oyster Tissue (OT) (NIST SRM 1566b). The relative standard deviation ranged from 0.5 to $9.1 \%$ and the relative error from 0 to $8.4 \%$, showing good precision and accuracy (Table 2).

\section{Fish in natura results (total $\mathrm{Hg}$ and $\mathrm{Ca}, \mathrm{Fe}, \mathrm{K}, \mathrm{Na}$, $\mathrm{Se}$ and $\mathrm{Zn}$ )}

The results obtained for the micronutrients and total $\mathrm{Hg}$ in natura (dry weight) for all of the 12 fish species in this study showed a significant concentration variation for the analyzed elements for each species (Figure 1 and 2). Carnivorous species are represented by Aruanã (Osteoglossum bicirrhossum), Surubim (Pseudoplalystoma fasciatum), Pescada (Plagioscion $s p p$ ) and Tucunaré (Cichla ocellaris spp) species (Carneiro et al., 2004; IBAMA, 2010). The non-carnivorous species include 


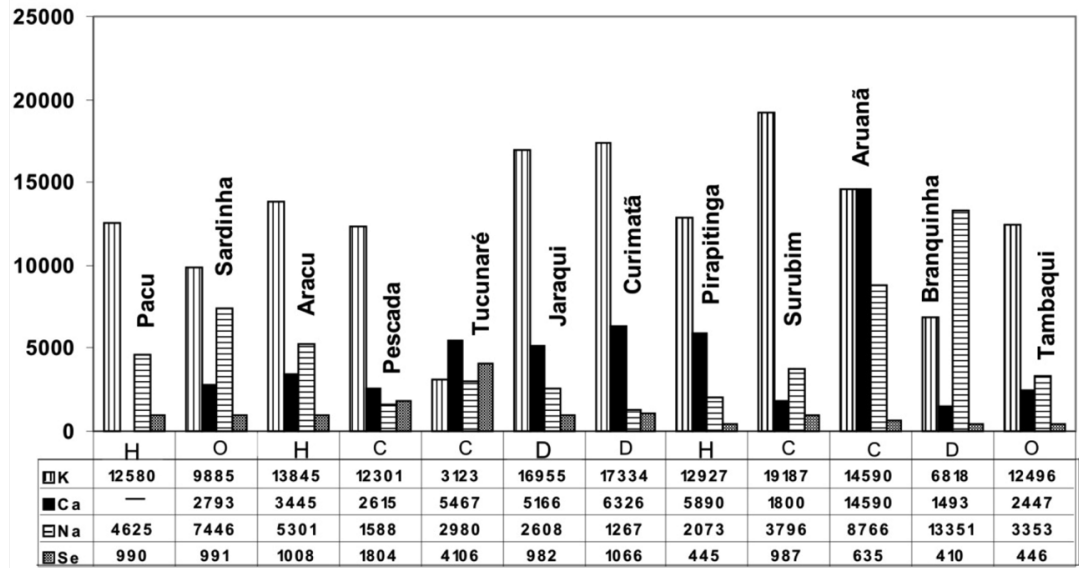

Figure $1-\mathrm{K}, \mathrm{Ca}$ and $\mathrm{Na}\left(\mathrm{mg} \mathrm{kg}^{-1}\right)$, and $\mathrm{Se}\left(\mu \mathrm{gg}^{-1}\right)$ contents in natura fish. $(\mathrm{n}=12) \mathrm{C}$ - Carnivorous, D - Detritivorous $\mathrm{H}$ - Herbivorous and 0 - Omnivorous.

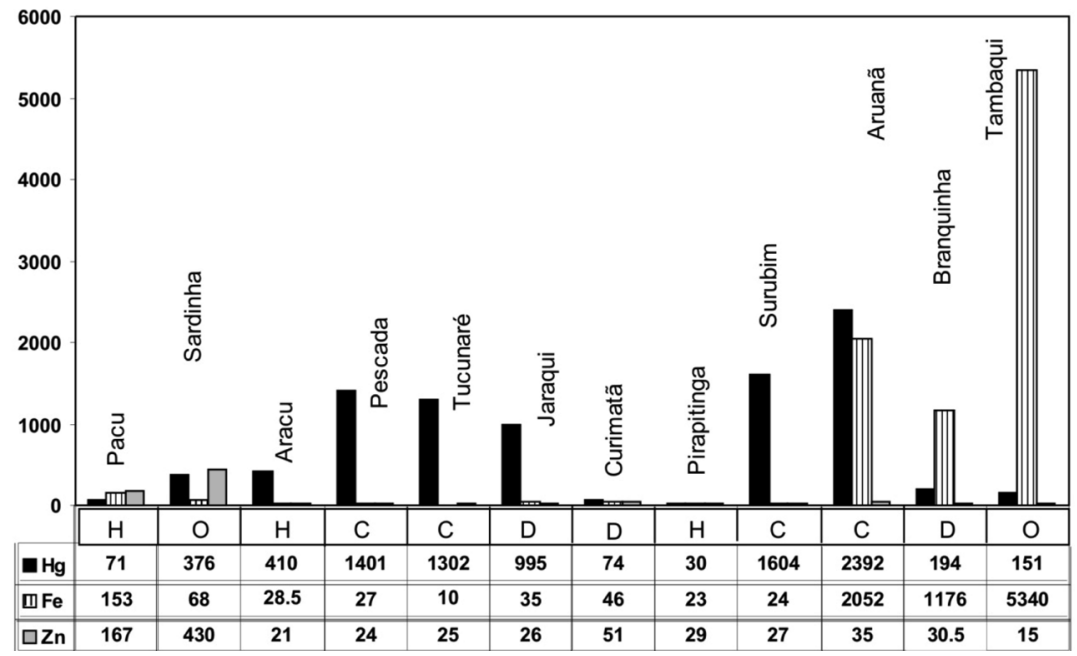

Figure 2 - $\mathrm{Hg}\left(\mu \mathrm{g} \mathrm{kg}^{-1}\right)$, and Fe and $\mathrm{Zn}\left(\mathrm{mg} \mathrm{kg}^{-1}\right)$ contents in natura fish. $(\mathrm{n}=12) \mathrm{C}$ - Carnivorous, $\mathrm{D}$ - Detritivorous $\mathrm{H}$ - Herbivorous and 0 - Omnivorous.

Table 2 - Instrumental Neutron Activation Analysis reference material results $\left(\mathrm{mg} \mathrm{kg}^{-1}\right)(\mathrm{n}=5)^{\mathrm{b}}$

\begin{tabular}{|c|c|c|c|c|c|c|c|c|c|c|c|c|c|}
\hline \multirow[t]{2}{*}{ Elements } & \multicolumn{2}{|c|}{$\begin{array}{l}\text { Tomato Leaves } \\
\text { (NIST SRM 1573a) }\end{array}$} & \multirow[t]{2}{*}{ RSD\% } & \multirow[t]{2}{*}{$\mathrm{RE} \%$} & \multicolumn{2}{|c|}{$\begin{array}{c}\text { Orchard Leaves } \\
\text { (NIST SRM - 1571) }\end{array}$} & \multirow[t]{2}{*}{ RSD $\%$} & \multirow[t]{2}{*}{$\mathrm{RE} \%$} & \multicolumn{2}{|c|}{$\begin{array}{c}\text { Oyster Tissue } \\
\text { (NIST SRM 1566b) }\end{array}$} & \multirow[t]{2}{*}{ RSD\% } & \multirow[t]{2}{*}{ RE\% } & \multirow{2}{*}{$\begin{array}{c}\mathrm{LD}^{\star} \\
\left(\mathrm{m} \mathrm{kg}^{-1}\right)\end{array}$} \\
\hline & Found & Certif. & & & Found & Certif. & & & Found & Certif. & & & \\
\hline $\mathrm{Ca}$ & $\begin{array}{l}51306 \pm \\
700\end{array}$ & $\begin{array}{l}50500 \pm \\
900\end{array}$ & 1.4 & 1.6 & $\begin{array}{l}20144 \pm \\
925\end{array}$ & $\begin{array}{c}20900 \pm \\
300\end{array}$ & 4.6 & 3.6 & $848 \pm 72$ & $838 \pm 20$ & 8.5 & 1.2 & 76 \\
\hline $\mathrm{Fe}$ & $347 \pm 5$ & $368 \pm 7$ & 1.4 & 5.7 & $298 \pm 8$ & $300 \pm 20$ & 2.7 & 0.7 & $\begin{array}{c}210.2 \pm \\
10,9\end{array}$ & $\begin{array}{c}205.8 \pm \\
6.8\end{array}$ & 5.2 & 2.1 & 1.05 \\
\hline K & $\begin{array}{c}26596 \pm \\
450\end{array}$ & $\begin{array}{l}27000 \pm \\
500\end{array}$ & 1.7 & 1.5 & $\begin{array}{c}13656 \pm \\
531\end{array}$ & $\begin{array}{c}14700 \pm \\
300\end{array}$ & 3.9 & 7.1 & $\begin{array}{c}6390 \pm \\
496\end{array}$ & $\begin{array}{c}6520 \pm \\
300\end{array}$ & 7.8 & 2.0 & 345 \\
\hline $\mathrm{Na}$ & $130 \pm 2$ & $136 \pm 4$ & 1.5 & 4.4 & $84 \pm 7$ & $82 \pm 6$ & 8.3 & 2.4 & $\begin{array}{c}3411 \pm \\
311\end{array}$ & $3297 \pm 50$ & 9.1 & 3.5 & 20.5 \\
\hline Se $\left(\mu \mathrm{g} \mathrm{kg}^{-1}\right)$ & ND & $54 \pm 3$ & ND & ND & $85 \pm 6$ & $80 \pm 1$ & 7.0 & 6.2 & $2234 \pm 93$ & $\begin{array}{c}2060 \pm \\
150\end{array}$ & 4.2 & 8.4 & 65 \\
\hline $\mathrm{Zn}$ & $38.5 \pm 0.2$ & $39.7 \pm 0.7$ & 0.5 & 3.0 & $25 \pm 2$ & $25 \pm 3$ & 8.0 & 0.0 & $\begin{array}{c}1491 \pm \\
102\end{array}$ & $1424 \pm 46$ & 6.8 & 4.7 & 0.53 \\
\hline
\end{tabular}

${ }^{\mathrm{b}} \mathrm{n}=$ number of determinations; ${ }^{\mathrm{c}} \mathrm{ND}=$ not determined; $\mathrm{RSD}=$ Relative standard deviation; $\mathrm{RE}=$ relative error 
Influência do processo de cocção no teor de mercúrio em peixes the detritivorous (Branquinha (Curimata laticeps), Curimatá (Prochilodus nigricans) and Jaraqui (Prochilodus insignis sp)), herbivorous (Aracu (Schizodar sp), Pacu (Mylossoma spp) and Pirapitinga (Piractus brachypomum) (Batistella et al., 2005) and omnivorous Sardinha (Triportheus elongatus $s p p$ ) and Tambaqui (Colossoma macropomum) (IBAMA, 2010).

$\mathrm{Hg}$ concentration in natura ranged from 30 (Pirapitinga) to 2392 (Aruanã) $\mu \mathrm{g} \mathrm{kg}^{-1}$ (dry weight). Brazilian legislation (ANVISA) establishes 2 distinct limits for total $\mathrm{Hg}$ concentration: for carnivorous fish species $\left(1 \mathrm{mg} \mathrm{kg}^{-1}\right)$ and for non-carnivorous species $\left(0.5 \mathrm{mg} \mathrm{kg}^{-1}\right)$. With the exception of Surubim, all the carnivorous fish species exceeded the established limit for total $\mathrm{Hg}\left(1 \mathrm{mg} \mathrm{kg}^{-1}\right)$. For non-carnivorous species, the exception was Jaraqui which presented $\mathrm{Hg}$ levels higher than the limit $\left(0.5 \mathrm{mg} \mathrm{kg}^{-1}\right)$ (ANVISA, 1998).

The Fe content (10 (Tucunaré) to $5340 \mathrm{mg} \mathrm{kg}^{-1}$ (Tambaqui)) in fish was very low for most fish species analyzed, with the exception of Aruanã, Branquinha and Tambaqui. Information on absorption and metabolism of iron in fish is scarse, but the process is generally the same as in other vertebrates (Watanabe et al., 1997).

The content of Selenium ranged from 410 (Branquinha) to 4106 (Tucunaré) $\mu \mathrm{g} \mathrm{kg}$. Selenium is essential for both humans and animals, including fish. Preliminary studies have verified the effect of feeding habitats and trophic level in the Se accumulation (Burger et al., 2001; Barwick \& Maher, 2003; Bhattacharya et al., 2003). All these studies concluded that carnivorous or piscivorous species generally present higher Se concentration in muscle tissue than omnivorous and herbivorous species. This study also found, in agreement with the literature, high Se content in the muscle tissue in Pescada and Tucunare, carnivorous species.

Muscle tissue $\mathrm{Zn}$ levels (15 (Tambaqui) to $430 \mathrm{mg}$ $\mathrm{kg}^{-1}$ (Sardinha)) were higher for omnivorous Sardinha and herbivorous Pacu. Fish can obtain zinc from dietary sources as well as from water. The gills and gastrointestinal tract are involved in the uptake of this element (Watanabe et al., 1997). Zinc is one of the most important environmental toxicants, yet it is essential in a wide range of biological processes (Glover \& Hogstrand, 2003). It places an important part in the growth, development and all living cells. It is also an essential micronutrient found in abundance in fish. It is a co-factor in metaloenzimes and regulatory proteins, including biosyntesis and DNA and RNA repair (Brabo et al., 1999).

Calcium is directly involved in the development and maintenance of the skeletal system and participates in several physiological processes (NRC, 1993). In vertebrates, $\mathrm{Ca}$ is complexed with $\mathrm{P}$ in hydroxyapatite to form the principal crystalline material of bone. The $\mathrm{Ca}$ requirement of fish is affected by the water chemistry and species differentiation (Lall, 2002). In the present study, Ca concentrations were widely spread (1493 (Branquinha) to $14590 \mathrm{mg} \mathrm{kg}^{-1}$ (Aruanã) showing the highest levels for Aruanã and Curimatã, carnivorous and detritivorous species, respectively.

Potassium, likewise sodium, is essential for normal body functions. In this study, the maximum $\mathrm{K}$ concentration (19187 $\mathrm{mg} \mathrm{kg}^{-1}$ ) was found in Surubim, while $\mathrm{Na}$ exhibits maximum concentrations of $13315 \mathrm{mg} \mathrm{kg}^{-1}$ in Branquinha, carnivorous and detritivorous species, respectively.

Regarding the content of micronutrients analyzed in this study, the fish species carnivorous and detritivorous presented the higher concentrations for $\mathrm{Ca}, \mathrm{K}, \mathrm{Fe}$ and Se. The omnivorous Sardinha presented the higher concentration for $\mathrm{Na}$ and $\mathrm{Zn}$.

Some variation in trace element content in freshwater fish species was observed. These are probably due to differences in geographical locations, season of the year, nature of fish diet and size.

\section{Cooking process evaluation $-\mathrm{Hg}$ loss}

The results obtained for total $\mathrm{Hg}$ in natura and after the three types of preparation (roasted, cooked and fried) for the 12 fish species showed a significant concentration variation for the analyzed elements: $\mathrm{Hg}$ (2392 to $16 \mu \mathrm{g} \mathrm{kg}^{-1}$ ) (Figure 3).

According to Figure 3, the $\mathrm{Hg}$ losses in each one of the cooking processes ranged from: 5.8 (Pescada) to $75.4 \%$ (Aruanã) for cooked; from 5.2 (Pescada) to 70.7\% (Aracu) for roasting and 15.4 (Tucunaré) to 68.5 (Aracu) for frying. The fish species that presented the highest $\mathrm{Hg}$ loss were Aracu (from 34 to 69\%) and Sardinha (from 22 to 70\%) after undergoing the 3 different cooking processes.

The cooked and frying processes resulted in higher $\mathrm{Hg}$ losses for Pacu, Pescada, Jaraqui, Curimatá, Surubin and Aruanã fish species. Most of these are detritivorous and carnivorous fish species. The higher $\mathrm{Hg}$ losses in the roasting process occurred for Sardinha, Aracu, Tucunaré, Pirapitinga, Branquinha and Tambaqui fish species. In this case most are omnivorous and herbivorous fish species.

According to the Kruskal-Walis test, the results showed a significant statistical variation for the different cooking processes $(\mathrm{p}<0.05)$.

The results obtained in the present study indicated that besides losses through cooking processes there is also a great variation in $\mathrm{Hg}$ content between the fish species analyzed.

As mentioned before it is already known that chemical constituents in fish vary between individuals of the same species in function of period and sampling site, habitat, gender, age, etc. This study also verified that carnivorous species presented higher $\mathrm{Hg}$ levels than non-carnivorous species. According to several studies undertaken in the region, these species present higher mercury contents than in the 


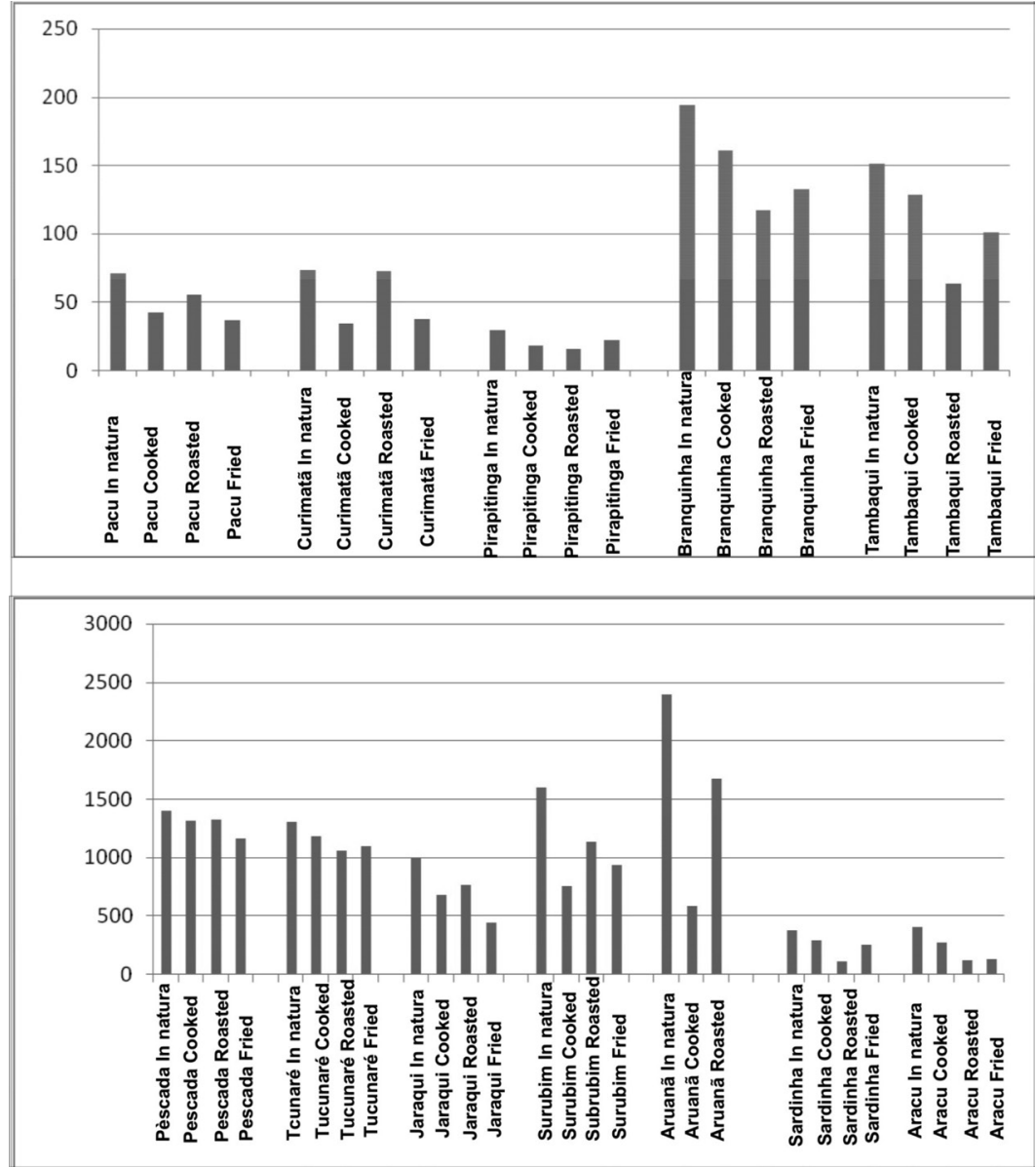

Figure 3 - Hg losses according to different cooking processes: Cooked, Roasted and Fried for the fish species analyzed.

non-carnivorous species since they occupy the highest trophic level of the food chain. The Surubim fish (piscivorous), Aruanã fish (carnivorous), Pescada fish (piscivorous) and Tucunaré fish (carnivorous) presented the highest Hg levels exceeding the limit set by Brazilian legislation - ANVISA of $1 \mathrm{mg} \mathrm{kg}^{-1}$ for total $\mathrm{Hg}$ in both cases for fish in natura and after cooking. For the others species analyzed total $\mathrm{Hg}$ levels were lower than the limit established by Brazilian legislation for non-carnivorous species $\left(0.5 \mathrm{mg} \mathrm{kg}^{-1}\right)$, except for Jaraqui.

Contrary to the findings of the present study, some authors have observed no reduction of mercury from frying, cooking or roasting. However, the conditions of these experiments and the fish species were not exactly the same.

Chicourel et al (2001) studied the $\mathrm{Hg}$ distribution throughout the body of blue shark (Prionace glauca) and the effects on mercury levels by frying and baking in a laboratory and a microwave oven. According to the results there was no significant statistical difference in $\mathrm{Hg}$ levels in the samples taken from regions near the head, or from central and tail parts, indicating homogenous distribution of the metal in muscles throughout the body. They also concluded that frying and baking did not affect original $\mathrm{Hg}$ levels present in blue sharks.

Mercury losses from flesh fish after two cooking process were investigated by Limaverde Filho et al (1999). The fish species used for frying process evaluation were: Traíra (Hoplias malabaricus) and Piraíba (Brachyplatystoma SSP), both from the Amazon region. The fish species Corvina and Piraíba "Brachyplatystoma ssp" were used for baking process evaluation. Results showed losses ranging from 0 to 30\% (dry weight basis). Such results indicate that fish consuming populations are not protected from mercury exposition by the studied cooking processes.

Since there is a great variability in the concentration levels of micronutrients as well as $\mathrm{Hg}$ between the fish species analyzed, we opted also to confirm the results using multivariate statistical techniques, principal component analysis and discriminate analysis, which aimed to identify 
sample groups with similar chemical composition for the determined elements.

Principal component analysis (PCA) showed that the first four principal components were responsible for $76.3 \%$ of the variations in the samples. The biplot presented in Figure 4, presents the first and second principal components. As can be seen from the biplot in Figure 4, samples group themselves according to feeding habits. The carnivorous group (C) was noticeably diverse from all the other species. The piscivorous species also came up as an isolated group. Some authors consider this as a subgroup of the carnivorous species. The herbivorous, detritivorous and omnivorous groups came up as a separate, disperse group. According to the same Figure 4, it is possible to observe that the elements that discriminate the groups are $\mathrm{Hg}$ and $\mathrm{Se}\left(2^{\text {nd }}\right.$ and $3^{\text {rd }}$ quadrants). This was not unexpected, as Se interacts with $\mathrm{Hg}$ and proteins, forming complexes that protect the organism from toxic effects of this metal on the kidneys, the intestines and nervous system in animals and humans.

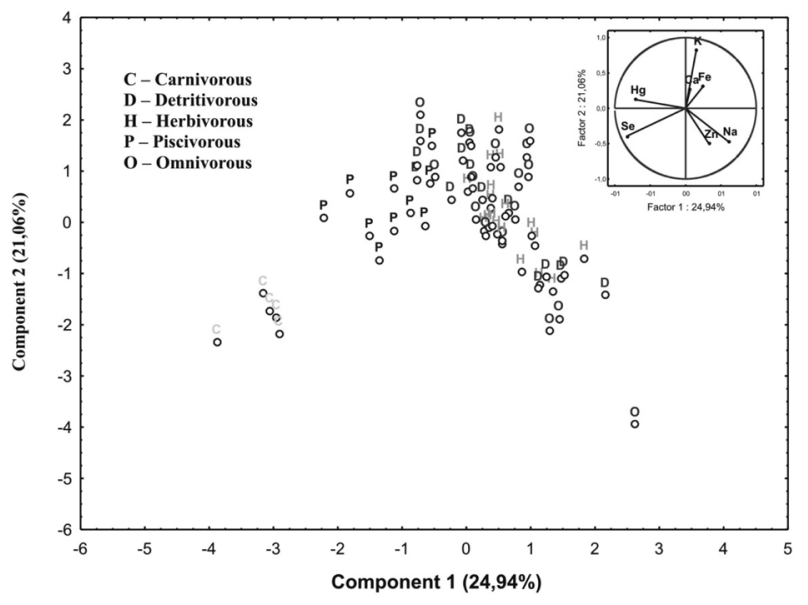

Component 1 (24,94\%)

Figure 4 - Biplot for the samples of fish in function of the alimentary diet of each species.

Considering the "a priori" proposition that the samples present a chemical composition that depends on the feeding habit of the species, the next step was to perform a discriminate analysis that linearly combined the original variables in order to maximize the differences between groups while, at the same time, minimizing the variations within each group (Beharav $\&$ Nevo, 2003). Figure 5 presents the discriminate scores in the plane formed by the axes corresponding to the first two discriminate functions. It is possible to confirm the inferences already observed in the principal component analysis previously discussed. Carnivorous and piscivorous species form two distinct groups. The omnivorous group is widely dispersed and has a small superposition on the group formed by herbivorous and detritivorous species, here considered as a single group, since they present similar chemical composition in the present samples.

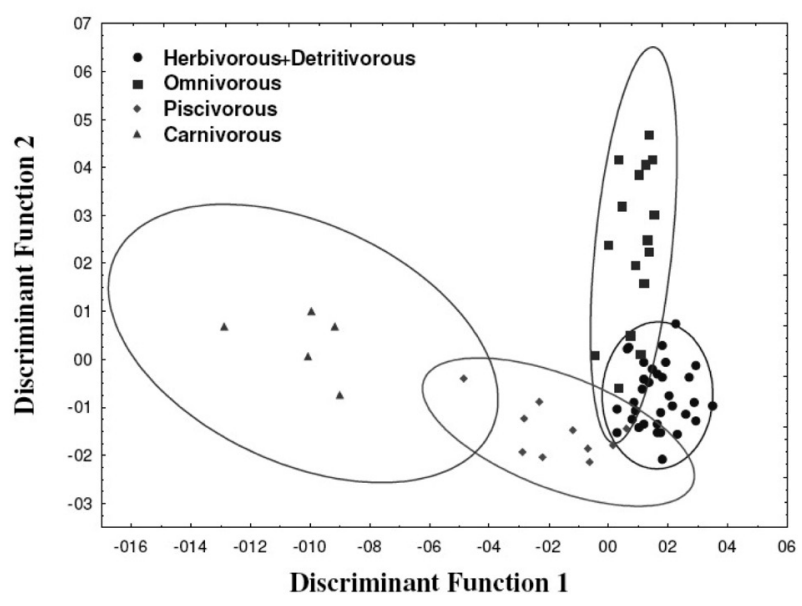

Figure 5 - Representation of the elementary chemical composition of the samples of fish in function of the alimentary diet.

\section{CONCLUSIONS}

Regarding the content of micronutrients analyzed in this study, the carnivorous and detritivorous fish species presented the higher concentrations for $\mathrm{Ca}, \mathrm{K}, \mathrm{Fe}$ and Se. The omnivorous Sardinha (Triportheus elongatus spp) presented higher concentrations for $\mathrm{Na}$ and $\mathrm{Zn}$.

In the present study, the cooked and frying processes resulted in higher $\mathrm{Hg}$ losses for Pacu, Pescada, Jaraqui, Curimatá, Surubin and Aruanã fish species, being most of them detritivorous and carnivorous feeding habits species. The higher $\mathrm{Hg}$ losses in the roasting process occurred for Sardinha, Aracu, Tucunaré, Pirapitinga, Branquinha and Tambaqui fish species, most of them omnivorous and herbivorous fish species.

For some species, Pescada, Surubim, Aruanã and Tucunaré these cooking processes were not sufficient to significantly decrease the exposure risk of this metal, as $\mathrm{Hg}$ values were higher than the Brazilian legislation limit of $1 \mathrm{mg} \mathrm{kg}^{-1}$ for predatory fish.

Nevertheless, the results of the present study and those from the literature indicate that further studies are needed. It is important to consider $\mathrm{Hg}$ content variability in fish and the relationship between inorganic $\mathrm{Hg}$ and $\mathrm{MeHg}$.

\section{ACKNOWLEDGMENTS}

The authors wish to thank CAPES for financial support and the INPA Food and Nutrition Laboratory, (Amazon National Research Institute), for the fish samples. 
Influência do processo de cocção no teor de mercúrio em peixes

\section{LITERATURE CITED}

ANVISA, 1998. Agência Nacional de Vigilância Sanitária. Legislação brasileira, portaria 685 (http://e-legis.anvisa.gov.br/leisref/ public/showAct.php?id=90). Acesso: 12/03/10.

Barwick, M. and Maher, W. 2003 Biotransference and biomagnification of selenium, copper, cadmium, zinc, arsenic and lead in a temperate seagrass community from lake Macquarie, NSW, Australia. Marine Environmental Research., 56:465-471.

Batistella, A.M.; Castro, C.O.; Vale, J.D. 2005. Conhecimento dos moradores da comunidade de Boas Novas, no lago Janauacá Amazonas, sobre os hábitos alimentares dos peixes da regiáo. Acta Amazônica, 35:51-54.

Beharav, A.; Nevo, E. 2003. Predictive validity of discriminant analysis for genetic data. Genetica, 119:259-267.

Bhattacharya, B.; Sarkar, S. K.; Das, R. 2003. Seasonal variations and inherent variability of selenium in marine biota of a tropical wetland ecosystem: implications for bioindicator species. Ecological Indicators, 2:360-367.

Brabo, E.S.; Santos. E.O.; Jesus, I.M.; Mascarenhas, A.F.; Faial, K.F. 1999. Níveis de mercúrio em peixes consumidos pela comunidade indígena de Sai Cinza na Reserva Munduruku, Município de Jacareacanga, Estado do Pará, Brasil. Cadernos de Saúde Pública, 15 (2):325-331.

Burger, J; Gainesc, K.F.; Boring, S.; Stephen, W.L.; Snodgrassd, J.; Gochfelde, M. 2001. Mercury and selenium in fish from the Savannah river: species, trophic level, and locational differences. Environmental Research, 87:100-108.

Carneiro, R.L.; Silva, J.A.M.; Albinati, R.C.B.; Socorro, E.P.; Neves, A.P. 2004. Uso de microcrustáceos (Dendrocephalus brasiliensis) na ração para tucunaré. Revista Brasileira de Saúde e Produção Animal, 5(1):18-24.

Chen, Y., A.D. Del Genio, and J. Chen, 2007. The tropical atmospheric El Niño signal in satellite precipitation data and a global climate model. J. Climate, 20: 3580-360.

Chicourel, E.L.; Sakuma, E.; Zenebon, O. 2001. Inefficacy of cooking methods on mercury reduction from shark. Archivos Latinoamericanos de Nutrición, 51(3):288-292.

Clarkson, T.W. 2002. The three modern faces of mercury. Environmental Health Perspectives. 110(1):11-23.

Fadini, P. S.; Jardim, W. F. 2001. Is the Negro River Basin (Amazon) impacted by naturally occurring mercury? The Science of the Total Environment, 175:141-150.

Farias, L. A.; Favaro, D.I.T.; Maihara, V.A.; Vasconcellos, M.B.A.; Yuyama, K.L.; Aguiar, J.P.L.; Alencar, F.J. 2006. Assessment of daily dietary intake of $\mathrm{Hg}$ and some essential elements in diets of children from the Amazon region. Journal of Radioanalytical and Nuclear Chemistry, 270:217-223.

Farias, L.A.; Favaro, D.I.T.; Vasconcellos, M.B.A. 2009. Determinação de mercúrio e metilmercúrio em amostras de cabelo e peixes. Revista do Instituto Adolfo Lutz, 68(3):451-460.
Favaro, D.I.T.; Afonso, C.; Vasconcellos, M.B.A.; Cozzolino, S.M.F. 2000. Determinação de Elementos Minerais e Traços por Ativação Neutrônica, em Refeiçôes Servidas no Restaurante da Faculdade de Saúde Pública/USP. Revista Ciência e Tecnologia de Alimentos, 20 (2):176-182.

Glover, C. N.; Hogstrand, C. 2003. Effects of dissolved metals and other hydrominerals on in vivo intestinal zinc uptake in freshwater rainsbow trout. Aquatic Toxicology, 62:281-293.

Hernández-García, M.T.; Martínez, M.C.; Masoud, T.A. 1998. Variación en la cantidad de mercurio en muestras de pescado sometidas a diversos procesos culinarios. Anais de Bromatologia, 40:291-297.

Horvat, M. 1996. Mercury analysis and speciation. In Environmental Sample in Global and Regional Marcury Cycles: Sources, Fluxes and Mass Balances, USA (eds), 131 pp.

IBAMA, 2010. Instituto Brasileiro do Meio Ambiente e dos Recursos Naturais Renováveis (http://www.ibama.gov.br/pescaamadora/ inicio/home.htm). Acesso: 13/03/2010).

IBGE, 2009. Instituto Brasileiro de Geografia e Estatística. IBGE Cidades@," (http://www.ibge.gov.br). Acesso: 01/02/2010.

Lall, S.P. 2002. The minerals. In: Halver, J.E., Hardy, R.W. (Eds.), Fish Nutrition, 3rd ed. Academic Press, San Diego, CA, 259-308.

Limaverde Filho, A. M.; Campos, R.C.; Goes, V.A.; Pinto; R.A.G. 1999. Avaliação da Perda de Mercúrio Total em Peixe Antes e Após os Processos de Fritura e Cocção. Ciência e Tecnologia de Alimentos, 19(1):19-22.

Moretti, G.; Marini, V.; Bortoli, A. 1990. Il mercurio e selenio nel pesce crudo e dopo cottura. Revista da Sociedade, a Ciência e Tecnologia de Alimentos, 19:35-38.

Morgan, J.N.; Berry, M.R.; Graves, R.L. 1997. Effects of commonly used cooking practices on total mercury concentration in fish and their impact on exposure assessments. Journal of Exposure Science and Environmental Epidemiology, 7:119-133.

NRC, 1993. Nutrient Requirements of Fish. National Academic Press, (National Research Council), Washington, DC, 200pp.

Silva-Forsberg, M.C.; Forsberg, B.R.; Zeidemann, V. 1999. Mercury Contamination in Humans linked to river. A Journal of the Human Environment., 28:519-520.

UNEP, 2002. Global Mercury Assessment. United Nations Environment Programme Switzerland: Geneva; 266 pp.

US EPA, 2001. Water Quality Criterion for the Protection of Human Health: Methyl Mercury. EPA 0823-R-01-001. US Environmental Protection Agency, Washington, DC, 300 pp.

Watanabe, T.; Kiron, V.; Satoh, S. 1997. Trace minerals in fish nutrition. Aquaculture, 151:185-207.

Recebido em 25/03/2010

Aceito em 06/05/2010 